УДК 781.68

DOI: $10.17223 / 22220836 / 21 / 14$

\title{
И.А. Шапошников
}

\section{ВЗАИМОСВЯЗЬ МУЗЫКАЛЬНОЙ ПОЭМНОСТИ И ЛИТЕРАТУРНОЙ ПОЭМЫ}

\begin{abstract}
В статье речь идет о взаимосвязях между феноменом музыкальной поэмности в широком смысле этого термина и жанром литературной поэмы. Эти взаимосвязи рассмотрены с точки зрения их способности помочь осмыслить явление музыкальной поэмности более четко. Эта проблема затрагивает и явление программности в музыке. Поэтому через связь музыкальной поэмности и литературной поэмы предлагается также и новая трактовка программности через введение и осмысление понятия потенциальной программы.

Ключевые слова: программность, поэмность, поэма, синергетика, эпичность, лиричность.
\end{abstract}

Поэмные жанры в музыке появились в XIX в. и, будучи показательными для музыкальных установок эпохи в целом, достаточно быстро получили широкое распространение. Пьесы, так или иначе причисляемые к поэмным, писали практически все значимые композиторы, родившиеся после 1800 г. Соответственно, и в музыковедческих трудах употребление терминов «поэма», «поэмность» не является единичным.

Сам термин «поэмность» представляется достаточно естественным для музыкального искусства. Но при всей кажущейся очевидности «поэмность» как конкретное понятие применяется редко и часто носит метафорический оттенок.

При этом поэмность явно предполагает параллели с литературной поэмой. Это часто вскрывается в анализах образного мира музыкальных поэм через привлечение литературных аналогий. Этот подход убедительно работает в программной музыке, которой, однако, музыкальные поэмы не исчерпываются. Таким образом, рассмотрение взаимосвязи поэмности в музыке и литературе представляется отдельной проблемой, в настоящее время разрешенной лишь частично и заслуживающей отдельного осмысления. Такое осмысление позволит связать музыкальную поэмность с литературной и, применяя наработки литературоведения в этой области, прояснить это понятие.

Жанр поэмы в литературе, хотя и является достаточно древним, в то же время имеет достаточно веские аргументы называться романтическим. Его окончательное формирование и яркий расцвет связываются именно с этой эпохой.

Если изначально смотреть на особенности этого жанра сквозь призму музыковедения, то, очевидно, следует отталкиваться от взгляда на поэму Б. Асафьева, который представлял ее как лиризацию эпического начала. При этом ученый уточняет, что, с его точки зрения, такова особенность поэмности как в литературе, так и в музыке.

Такая позиция, бесспорно, хорошо согласуется с важными чертами поэмы, на которые указывают и многие литературоведы. 
Прежде всего, стоит обратить внимание, что поэмой в литературе называется большое эпическое стихотворное произведение, принадлежащее определенному автору. То есть поэма в первую очередь связана с эпичностью. В немецкой теоретической литературе термину «поэма» даже соответствует термин «Еріk», совпадающий с русским «эпос».

При этом через поэзию эпичность поэмы неизбежно в большей или меньшей степени всегда связывалась с лирическим началом, а через него и с музыкальным. По определению А.Н. Веселовского, поэма появилась через циклизацию песен и повествований, т.е. процесс лиризации эпоса может быть представлен как настолько древний и фундаментальный, что поэма может уже определяться не только как синтетический, а даже как синкретический лироэпический жанр.

Однако процесс лиризации эпоса, хотя и представляется достаточно древним, видимо, не всегда был одинаково интенсивен. Поэтому яркими образцами литературной поэмы, фактически сформировавшими понимание этого жанра в настоящее время, являются именно произведения поэтов эпохи романтизма.

Б. Асафьев, адаптировавший понятие «поэма» для музыкального искусства, описывая процесс лиризации эпического начала, писал, что этот процесс дает художественный эффект «исхождения лирического начала в мир», «за пределы личных излияний». В таком описании этого явления очевидно, что под «миром» понимается эпическое начало, а сам момент проецирования лирического начала (причем заостренно-авторского, личного переживания) на некоторое повествование действительно особенно характерен для поэм начиная с романтической эпохи. Это позволяет определить поэмность в целом как «конструктивный принцип романтизма» [1].

Такое более расширенное понимание поэмы через осмысление самих механизмов, образующих нормы этого жанра, позволяет уже в самом литературоведении рассматривать поэмность широко, даже за пределами поэтических текстов. Например, Ю. Манн рассматривает влияние романтической поэмы на романтическую прозу и драму, выделяя при этом три опорных пункта, связанных именно с лирическим началом. Очевидно, что причина такой сфокусированности исследователя на проявлении лирического обусловлена тем, что наличие повествовательности в прозе очевидно и не нуждается в подтверждении.

Напротив, для музыкальных произведений, не относящихся к синтетическим жанрам, лиричность является свойством, органично связанным с самими особенностями музыкального языка. Повествовательность же не только прямо не вытекает из этих свойств, но и, казалось бы, противоречит им, требуя как минимум гораздо большей образной конкретности. Поэтому очевидны и отличия музыкальной повествовательности от литературной. Если для литературной повествовательности действительно характерна передача какого-либо сюжета, то в музыке повествовательность сама по себе становится образной характеристикой, наличие которой предполагает лишь ощущение глубинного сходства музыкального процесса с принципом развертывания некоторого рассказа. При этом произведение будет отличаться полным отсутствием сколько-нибудь конкретного сюжета или хотя бы предмета повествования.

В отдельных случаях в музыкальном произведении может создаваться не только само ощущение повествовательности, но даже и видимость развертывания сюжета. Но этот сюжет остается настолько неконкретным и «развеще- 
ствленным», что намеки композитора и даже конкретные программные указания часто не в состоянии сделать его до конца отчетливым.

Таким образом, поэмность в музыке, трактуемая сходным с поэмностью в литературе образом как совмещение лирического и эпического начал, все же предполагает и совершенно иные особенности, связанные с особенностями музыкального языка, изначально нацеленного на лиричность.

Так, основной лирический опорный пункт поэмности в прозе Ю. Манн связывает с общей организацией повествования - это параллелизм судеб автора и центрального персонажа [2].

Эта важная черта поэмности в литературе совершенно видоизменяется в музыке, поскольку музыкальное содержание изначально воспринимается именно как субъективно-авторское. Поэтому для создания необходимого параллелизма следует, напротив, придать образам произведения черты некоего вышедшего за пределы личности автора переживания и подчеркнуть его связанность с образами внешнего мира.

И здесь трудно переоценить значимость для музыкальной поэмности даже самого ощущения эпичности, о котором говорилось выше. Не случайно для Ф. Шопена было важно просто определить свои поэмные сочинения как баллады, что подчеркивает исключительно присутствие эпичности. Этого было также достаточно, с точки зрения композитора, чтобы подчеркнуть нужное направление для их исполнения и восприятия. Ф. Лист в своих программах и названиях также часто указывает на образы, связанные с «делами давно минувших дней»: Тассо, Данте, Фауст, Мазепа и т.д.

Образующаяся таким образом программность в поэмных произведениях явно отличается от общепринятой трактовки программности огромной степенью вероятностности, которая особенно очевидна в произведениях Ф. Шопена.

Такая видимость наличия в произведении некоего неконкретизированного сюжета может быть охарактеризована через расширение понятия программности.

Подобное расширение понятия «программность» уже предлагалось Ю. Тюлиным. Исследуя мазурки Шопена, ученый пришел к выводу, что их образный мир уместно рассматривать с точки зрения «скрытой программы» [3]. При этом, как представляется, под термином «скрытый» можно в данном случае подразумевать содержащиеся в произведении намеки автора на черты сходства с явлениями реального мира, скрытые автором. И действительно, в исследовании рассматриваются усложненная вопросно-ответная структура в мелодике либо заостренная диалогичность различных голосов в качестве свидетельств некой скрытой образности, некоторого скрытого диалога и т.д.

Под предложенным же нами термином «потенциальная программа» [4] понимаются несколько иные особенности образного мира музыкальных произведений, ярко проявившиеся в творчестве таких композиторов, как Лист и Шопен.

Важнейшей особенностью потенциальной программы являются ее открытость и смысловая вариативность. Потенциальная программа - это то, что может и стремится домыслить исследователь, либо исполнитель, либо воспринимающий. При этом имеются и факты биографии, и некоторые «намеки» либо даже прямые указания со стороны композитора на действительно предполагаемую им тематику произведения. Но при этом такая тематика не 
оказывает непосредственного и прямолинейного воздействия на основные драматургические ходы произведения.

Это воздействие можно описать синергетическим термином «малые резонансные воздействия» [5], подразумевая под ним именно усиление за счет резонанса некоторых процессов саморазвивающейся системы, которые в конечном итоге отчетливо влияют и на путь ее развития.

Источником таких воздействий как раз и будет являться та образность, которая составляет некую глубинную основу потенциальной программы. Эти потенциально программные импульсы, влияя на развитие образов в произведении, видоизменяют его конечную форму, сообщая ей индивидуализированность и запечатлеваясь в ней. Поэтому по ходу развития образов можно предполагать и источник воздействия (не стоит забывать, что источник именно предполагается, с большей или меньшей долей вероятности).

При этом развитие образов остается полностью в рамках имманентномузыкальных драматургических принципов, поэтому исследователи часто осмысляют все свободные и смешанные формы, а также так называемую поэмную форму с точки зрения классических формообразующих принципов, воздействие которых усложнено, но не ослаблено.

Таким образом, форма, содержащая потенциальную программность и поэмность, в музыке предполагает также и переосмысление норм формообразования в сторону большей свободы. Это обусловлено желанием передать ненормированные взаимоотношения между образами, а именно выразить их сквозь призму острого индивидуализированного авторского начала. В то же время это продиктовано и необходимостью создать ощущение присутствия оригинальной конкретики, которой обладает уже некий сюжет, а не типовой, по сути внеличный инвариант музыкальной формы.

При этом так называемая поэмная форма обладает чертами слитноциклической формы. Это является еще одним своеобразным звеном, связывающим музыкальную и литературную поэмность, которая, по наблюдениям А.Н. Веселовского, образовалась через циклизацию песен и повествований.

Таким образом, взаимодействие лирического и эпического элементов, которое Б. Асафьев предлагал трактовать как в музыкальной, так и в литературной поэмности в качестве «исхождения лирического начала в мир», в музыке проявляется в стремлении композитора создать в поэмном произведении ощущение обостренно-личного и при этом потенциально программного, т.е. содержащего импульсы, посылаемые образами внешнего мира. Углубленное и всестороннее изучение этого взаимодействия, хотя и вытекает из наблюдений относительно поэмности в литературе, однако способно внести некоторые новые черты и в осмысление музыкальной поэмности.

\section{Литература}

1. Лейдерман Н.Л. Жанровые системы литературных направлений и течений // Взаимодействие метода, стиля и жанра в советской литературе. Свердловск, 1988. С. 4-16.

2. Сухорукова Ю.А., Хрящева Н.П. Трансформация принципа «поэмности» в новелле Паустовского «Равнина под снегом» // Вестн Удмурт. ун-та. 2011. № 5/4 [Электронный ресурс]. URL: http://cyberleninka.ru/article/n/transformatsiya-printsipa-poemnosti-v-novelle-k-g-paustovskogo-ravnina-pod-snegom (дата обращения: 10.01.2016).

3. Тюлин Ю.Н. О программности в произведениях Шопена. Л. : Госмузиздат, 1963. 55 с.

4. Коляденко Н.П., Шапошников И.А. Программность и поэтичность в романтической музыке // Музыкальная академия. 2015. № 3. С. 156-159. 
5. Князева E.Н. «Мыслить синергетически-значит мыслить диалектически» [Электронный pecypc]. URL: http://www.metodolog.ru/00162/00162.html (дата обращения: 10.01.2016).

Shaposhnikov Ivan A. Novosibirsk State Conservatory (Novosibirsk, Russian Federation).

E-mail: shaposhnikovi@mail.ru

DOI: $10.17223 / 22220836 / 21 / 14$

RELATIONSHIP MUSICAL AND LITERARY POETICALNESS POEM

Key words: software, poeticalness, poem, Synergetics, epic, lyrical.

Poemic genres in music appeared in the XIX century and quickly became widespread. Poemic pieces had been written by all famous composers born after 1800 , thereby it is common to use the terms "Poem", "Poemic" in the musicological researches.

Poemnity clearly suggests parallels with poem in literature. This aspect is often revealed in the analysis of imagine world of music poems by attracting literary analogies. This approach is working excellent in the program music, but there are many musical poem without program.

If one initially look at the features of the literary poem through the lens of musicology, one should start from the view of the poem of B. Asafiev who represented it as lyrical changes of epic component in music and in literature too. This position is in certainly good agreement with the important features of the poem, which is shows by much literature researchers.

This comprehension of the poem is more advanced by understanding of the mechanisms themselves, forming the bases of the genre, and is used in the literary allowing poemnity widely regarded, even outside of poetic texts. For example, J. Mann describes the romantic poem influence on the romantic prose and drama, by showing three important points, which are associated with a lyrical element. Obviously, the reason for this focus of researchers at the lyrical element is due to the fact that presence of narrative element in prose is obvious and does not require confirmation.

On the contrary, for the music pieces, from non-synthetic genres, lyricism is a property that is closely connected with the basic features of the musical language. Narrative element is not directly derived from music properties, but it is also seemed to contradict them, requiring the much more imaginative clearly as the minimum.

Thus, poemnity in music, described similar to poemnity in the literature as a way to combine the lyric and epic elements, still implies a very different features associated with the peculiarities of the musical language, which was originally focuses on lyricism.

And it is difficult to overestimate the importance from music poemnity even the feeling of epic that music can create.

However, in this case, the programnity also has place, but it is clearly different from the generally accepted interpretation of possibility that can be reflected in the concept of the «potential program».

The impact of potential program on the development of musical images is not direct. It can be described by synergistic term «small resonance effects», which are increase some processes musical drama by resonant impact, and it can significantly affect the outcome shaped development.

Therefore, in the immanent musical development one can start to see the influence of «images of the outside world», there appears narrative, epic, which is needed to poemnity.

\section{References}

1. Leyderman, N.L. (1988) Zhanrovye sistemy literaturnykh napravleniy i techeniy [The genre systems of literary movements and trends]. In: Leyderman, N.L. (ed.) Vzaimodeystvie metoda, stilya $i$ zhanra $v$ sovetskoy literature [Interaction of the technique, style and genre in Soviet literature]. Sverdlovsk: Sverdlovsk State Pedagogical University. pp. 4-16.

2. Sukhorukova, Yu.A. \& Khryashcheva, N.P. (2011) Transformation of the principle of "poetic structure" in Paustovsky's short story "Plain in snow". Vestnik Udmurtskogo universiteta - Bulletin of Udmurt University. 5(4). pp. 78-82. (In Russian).

3. Tyulin, Yu.N. (1963) O programmnosti v proizvedeniyakh Shopena [About programme works of Chopin]. Leningrad: Gosmuzizdat.

4. Kolyadenko, N.P. \& Shaposhnikov, I.A. (2015) Programmnost' i poetichnost' v romanticheskoy muzyke [Programme and poetic character in romantic music]. Muzykal'naya akademiya. 3. pp. 156-159.

5. Knyazeva, E.N. (2000) Myslit' sinergeticheski znachit myslit' dialekticheski' [To think synergistically is to think dialectically]. [Online] Available from: http://www.metodolog.ru/00162/00162.html. (Accessed: 10th January 2016). 